\title{
HAIKAI DA PRIMA VERA
}

Juliana Braga Guedes é professora de Literatura na Universidade Regional do Cariri (URCA) e Mestre em Literatura Comparada pela Universidade Federal do Ceará (UFC).

E-mail: guedesbjuliana@gmail.com

No rigor do clima

o ígneo sagrado

meio mulher, meio cavalo. 